\title{
The Effect of Student Team Work Learning (Stwl) Towards Students' Reading Comprehension
}

\author{
Terasne $^{1}$, Dira Permana ${ }^{2}$, Tri Setianingsih ${ }^{3}$ \\ ${ }^{1}$ terasne@ikipmataram.ac.id, ${ }^{2}$ dirapermana@ikipmataram.ac.id, ${ }^{3}$ trisetianingsih@ikipmataram.ac.id \\ ${ }_{1,2,3}$ Universitas Pendidikan Mandalika Mataram
}

\begin{abstract}
This research was aimed at finding out whether or not Student Team Work Learning Strategy (STWL) has positive effect on students' reading comprehension. The research was pre experimental with one pre-test post-test design. The sample of the study was second grade students of MA Nurul Muhsini Jomang Batu Jai Lombok Tengah which consisted of one class 30 students. The instrument used was reading test in the form of multile choice test and objective test which were consited of 25 items. The score was analyzed by using descriptive and inferential analysis. Descriptive analysis was used to describe mean, mode, median, and standard deviation of group, and inferential analysis was used to describe the value of t-test for comparison between t-table. It was showed that the value of t-test $=5.411$ was higher than the value of t-table $=1.692$. Alternatively, using Student Team Work Learning Strategy has positive effect on students' reading comprehension at second grade students of MA Nurul Muhsini Jomang Batu Jai Lombok Tengah.
\end{abstract}

Keywords: student team work learning, reading comprehension.

\section{INTRODUCTION}

Reading is one of core language skills that the students have to acquire. It means that reading is a process which is applied and conducted by a reader to acquire a message that has been told by a writer in writing script. According to Brown (2004: 185) reading is likewise a skill that teachers simply expect learners to acquire. However, reading for general comprehension requires very rapid and automatic processing of words, strong skill in forming a general meaning representation of main ideas, and efficient coordination of many processes under much emitted time constraints. It is one of skills in English concerning the ability to understand information in a text and interpret it appropriately.

During the researcher conducting teaching practice, some students faced difficulties in reading subject. The first difficulties faced by the student in reading subject is that the students found it difficult to understand the reading text, second the students' lack of vocabulary mastery, and third the students found it difficult to find main ideas of reading texts.

Based on the background of the study above, the statement of the problem can be stated as follow: "Is there any significant effect of Student Team Learning strategy towards students' reading comprehension at second grades student of Nurul Muhsini Jomang Batu Jai Lombok Tengah. Based on the statement of the problem above, the researcher formulates the purpose of 
the study as follow: To find out the significant effect of Student Team Learning strategy toward students' reading comprehension at ten grades student of Nurul Muhsini Jomang Batu Jai Lombok Tengah This study was expected to have some significances both theoretically and practically in teaching reading. 1 Theoretically: a) For the students: the result of this study is expected to give the theoretical information on the positive effect of Student Team Learning strategy in reading, because in the teaching and learning process the students shall work together in groups. b)For the teacher: the result of this study as input and information for the teacher in teaching and learning process to encourage the students to be more interested in learning. 2)Practically : a) For the students: this study is expected will be able to ease the students to comprehend and to answer the question within the text. B) For the teacher: practical significant as input to the English teachers in order to apply theStudent Team Learning staregy. The researcher focused on the effect of Student Team Learning strategy toward ten grade students' reading comprehension of MA at second grades student of Nurul Muhsini Jomang Batu Jai Lombok Tengah.

According to Grellet (2004: 7) reading is a constant process of guessing, and what one bring to the text is often more important, than what one finds in it.Based on the definition above reading is an art to understand the purpose of the writer by guessing continuously and what is brought to the text is often more important and also reading is a process to find out the ideas contained in the reading. Harmer (2007: 99) reading is useful for language acquisition. Provided that students more or less understand what they read, the more they read, the better they get at it.Reading is can add a lot of knowledge and good language mastery (see also Syamsurrijal, 2020).

According to Chelsea (2004: 24) there are nine indicators of reading those will be explained as follow: a) Main idea one of the most important component in written text is main idea or general statement. Writer often put the main idea or general statement in the beginning, middle, and in the end of the next. Main idea gathered all of the ideas in paragraph. b) Vocabulary refers to lexical items appear in the next, in reading test, test taker often asked to determine the meaning of a word. c) Specific fact or detail information refers to the reader ability of finding the detail information given in the text. d) Expectation refers to question about what is not mention in the text. This question aims to test the reader whether they really understand the text or not. Location of information Author often organize their idea or specific information in different way in a paragraph. e) Inferences, $t$ is important for readers to make their own perception of the text they read. Author rarely write the explicit information in the 
main idea or general statement. Therefore the reader ought to have good ability in inferring text. f) References the a author often use specific vocabulary as reference for particular sentence means. Reference often causes confusion for reader while refer a word to specific term.g) Paraphrased sentence, the first readers read the paragraph and think about what it means while reading. Then readers ask themselves to identify the main idea of the paragraph. h) Sentence insertion, in this stage readers allowed to put a sentence in paragraph and make it into wellorganized paragraph.

Student Team Achievement Division is known as Students' Team Work Learning. It is one of a set of instructional strategy developed and researched by Robert E. Slavin at John Hopkins University. It is one of the oldest cooperative learning. According to Slavin (1997: 3) Students' Team Learning is a strategy that will achieve student humanistic educational goals and basic skill learning goals instead of achieving one at expense of the other. When we place the students in learning teams, they will know that a group of peers support their academic efforts. Because for a team to be successful, all team members must do their best. Students Team Learning expects students learn together with other team matters in a small team to study the subject that is presented. In the technique, the smartest students are expected to teach the lowest students until they understand and master the subject being presented. They are not only study to answer the task correctly but also how to make all the group members understand and master the subject, so all the group members can answer the task correctly. Students are divided into small group consist of four to five group members. The groups must be totally heterogeneous. The groups are mixed in high, average, and low level, boys, girls, different ethnicity and different religion. Do not allowstudents choose their own teams, because they will prepare to choose others like themselves. Educational research has demonstrated that heterogeneous teams made up of high and low achievers, boys and girls, blacks, whites, and Hispanics, can be successfully transplanted from the playing field to the classroom. Three Students' Team Work Learning techniques have now been extensively researched and found significantly increase students learning.

The function of teaching procedures is to help the teacher or the researcher on how to apply this approach. There are six procedures of Students Team Learning Approach as follows: a) Teacher assigns students into small groups consist of four to five students from different level, gender, and ethnicity. b) The teachers ask the group naming their own group. c) The teacher gives class presentation. Teachers explain the problems, giving the data, and giving the example. It is done to introduce the concept and encourage students' motivation. d) The teacher 
given the worksheet to the groups. In their teams they discuss the problem, compare the answer and correct any misconceptions. The students are not only expected to answer the worksheet but also to understand the subject. The group gets success it all the members understand the subject. e) The teacher asks every group to read their answering and their argument, and other groups are allowed to give their opinion. f) After two periods of teacher presentation and group practice, teacher gives students an individual quizzes. In this way, students are not allowed to help each other. This activity is to measure that each student is individually responsible for knowing the subject.

\section{RESEARCH METHOD}

This research is an experimental research. According to Kothari (2004: 5) "experimental research is characterized by much greater control over the research environment and in this case the variables are manipulated to observed their effect on the variables. This study applies a pre-experimental research design, and using one group pre-test and post-test design.

Table 1. One group Pre-Experimental design

\begin{tabular}{|c|c|c|}
\hline O1 & $\mathbf{X}$ & O2 \\
\hline Pre test & $\begin{array}{c}\text { Student Team Work } \\
\text { Learning }\end{array}$ & Post test \\
\hline
\end{tabular}

\section{Where: O1: Pre Test \\ $\mathrm{X}$ : Student Team learning \\ O2: Post Test}

According to Miller (2005: 53) a population is defined as collection of all the possible object, people or scores of a particular type. Based on the statement above, the sample of this study was one class (second grades class), at second grade students of MA Nurul Muhsini Jomang Batu Jai Lombok Tengah wich ware consisted of 30 students.

The sampling technique used in this research was cluster random sampling. Kothari (2004: 16) suggests that cluster random sampling involves grouping the population and then selecting groups or groups rather than individual elements to be included in the sample.

Instrument is a thing or tool that the researcher used in testing students' reading comprehension. The researcher used the test of instruments as follows: The researcher gave test especially in reading, in the form of multiple choices. The multiple choice consist of ( $a, b, c, d$, and e). The function of this test is to find out the effect of Student Team Learning strategy in reading. In reading test the researcher gave 25 questions. The researcher scored1for each correct 
answer and 0 for incorrect answer. The student obtained score of 100 if all of the answer were correct.

\section{FINDINGS AND DISCUSSION}

The purpose of this research was to know wheter Student Team Work Learning (STWL) strategy has significant effect in teaching reading comprehension at second grade students of MA Nurul Muhsinin Jomang Batu Jai Lombok Tengah. The researchers took one class as the sample with total subject of 30 students. The description of the data presented in table below:

Table 2. Students' score of Pre-test and Post-test

\begin{tabular}{|c|c|c|c|c|c|}
\hline No. & Student & Pre-test & Post-test & Deviation & Deviation square \\
\hline 1. & A & 12 & 76 & 64 & 4096 \\
\hline 2. & B & 32 & 84 & 52 & 2704 \\
\hline 3. & C & 28 & 80 & 52 & 2704 \\
\hline 4. & D & 20 & 76 & 56 & 3136 \\
\hline 5. & E & 28 & 84 & 56 & 3136 \\
\hline 6. & F & 44 & 88 & 44 & 1936 \\
\hline 7. & G & 40 & 84 & 44 & 1936 \\
\hline 8. & H & 24 & 80 & 56 & 3136 \\
\hline 9. & I & 68 & 72 & 4 & 16 \\
\hline 10. & J & 40 & 72 & 32 & 1024 \\
\hline 11. & K & 64 & 80 & 16 & 256 \\
\hline 12. & L & 36 & 76 & 40 & 1600 \\
\hline 13. & M & 12 & 80 & 68 & 4624 \\
\hline 14. & O & 40 & 84 & 44 & 1936 \\
\hline 15. & F & 36 & 76 & 40 & 1600 \\
\hline 16. & Q & 24 & 80 & 56 & 3136 \\
\hline 17. & R & 64 & 80 & 16 & 256 \\
\hline 18. & S & 28 & 88 & 60 & 3600 \\
\hline 19. & T & 32 & 80 & 48 & 3230 \\
\hline 20. & U & 24 & 92 & 68 & 4624 \\
\hline 21 & V & 32 & 68 & 36 & 1296 \\
\hline 22. & W & 20 & 80 & 60 & 3600 \\
\hline 23. & X & 52 & 72 & 20 & 400 \\
\hline 24. & Y & 44 & 80 & 36 & 1296 \\
\hline 25. & Z & 52 & 84 & 32 & 1024 \\
\hline 26. & A1 & 64 & 80 & 16 & 256 \\
\hline 27. & A & 40 & 80 & 40 & 1600 \\
\hline 28. & A3 & 52 & 84 & 32 & 1024 \\
\hline 29. & A 4 & 28 & 88 & 60 & 3600 \\
\hline 30. & A5 & 64 & 80 & 16 & 7236 \\
\hline & Total & 1352 & 2828 & 1476 & \\
\hline & & & & & \\
\hline
\end{tabular}




\section{Data Analysis}

The researchers calculated rhe result of pre-test done in experimental group towards the student's reading skill. The data showed that Descriptive Statistics Based on the result of the descriptive computation, the researcher can present the following table.

Table 3. Statistic of pre-test,post-test Experimental group

\begin{tabular}{|l|r|r|}
\hline & \multicolumn{1}{|c|}{ pretest } & \multicolumn{2}{|c|}{ posttest } \\
\hline $\mathrm{N}$ Valid & 30 & 30 \\
$\quad$ Missing & 0 & 0 \\
Mean & 38.63 & 80.80 \\
Median & 36.00 & 80.00 \\
Mode & 64 & 80 \\
Std. Deviation & 16.086 & 5.384 \\
\hline
\end{tabular}

Based on the output table of SPSS 21 above, that before the students were given the treatment used the strategy, the initial ability of the students pre-test score in experimental group showed that mean was 38.63 , the median score was 36.00 , the mode score was 64 and the standard deviation was 16.086 , and post-test score in experimental group showed that mean was 80.80 , the median score was 80.00 , the mode score was 80 and the standard deviation was 5.384. The researcher would also like to show the frequency of interval of pre-test and post-test experimental group and bar chart to present the data. The detail is shown in the table and figure below:

Table 4. Frequency pre-test and post-test Pre-test

\begin{tabular}{|c|c|c|c|c|c|}
\hline & & Frequency & Percent & Valid Percent & Cumulative Percent \\
\hline \multirow[t]{13}{*}{ Valid } & 12 & 2 & 5.7 & 5.7 & 5.7 \\
\hline & 16 & 1 & 2.9 & 2.9 & 8.6 \\
\hline & 20 & 2 & 5.7 & 5.7 & 14.3 \\
\hline & 24 & 3 & 8.6 & 8.6 & 22.9 \\
\hline & 28 & 4 & 11.4 & 11.4 & 34.3 \\
\hline & 32 & 4 & 11.4 & 11.4 & 45.7 \\
\hline & 36 & 2 & 5.7 & 5.7 & 51.4 \\
\hline & 40 & 4 & 11.4 & 11.4 & 62.9 \\
\hline & 44 & 3 & 8.6 & 8.6 & 71.4 \\
\hline & 52 & 4 & 11.4 & 11.4 & 82.9 \\
\hline & 64 & 5 & 14.3 & 14.3 & 97.1 \\
\hline & 68 & 1 & 2.9 & 2.9 & 100.0 \\
\hline & Total & 30 & 100.0 & 100.0 & \\
\hline
\end{tabular}


Based on the table 4 above, can be seen the distribution of the data pre-test score of experimental group with a frequency of students in each score. The data presented show that from 30 students of the experimental group have a range of score ranging from 12 to 68 . The range of the score is 56 , so the data can still be presented in the single of distribution table.

Table 5. Frequency post-test experimental Post-test

\begin{tabular}{|rl|r|r|r|r|}
\hline Valid & 68 & 1 & 2.9 & 2.9 & 2.9 \\
& 72 & 3 & 8.6 & 8.6 & 11.4 \\
& 76 & 5 & 14.3 & 14.3 & 25.7 \\
& 80 & 12 & 34.3 & 34.3 & 60.0 \\
84 & 8 & 22.9 & 22.9 & 82.9 \\
& 88 & 5 & 14.3 & 14.3 & 97.1 \\
92 & 1 & 2.9 & 2.9 & 100.0 \\
& Total & 30 & 100.0 & 100.0 & \\
\hline
\end{tabular}

Based on the table 5, it can be seen the distribution of the data post-test score of experimental group with a frequency of students in each score. The data presented show that from 35 students of the experimental group have a range of score ranging from 68 to 92 . The range of the scores is not than more 24 , so the data can still be presented in the single of distribution table.

\section{Inferential Analysis}

After having treatment, the researcher used statistic hypothesis to calculate the result of t-test that could be seen as follow:

$$
\begin{aligned}
& \mathrm{t}=\frac{\mathbf{m d}}{\sqrt{\frac{\sum D^{2}}{N(N-1)}}}=\frac{42.17}{\sqrt{\frac{72.305}{35(35-1)}}}=\frac{42.17}{\sqrt{\frac{72.305}{1.190}}} \\
& =\frac{42.17}{\sqrt{60.7605042017}}=\frac{42.17}{7.7949024498} \\
& =5.4099458295
\end{aligned}
$$

So, $t_{\mathrm{o}}(\mathrm{t}$ - obtain $) \geq \mathrm{t}_{\mathrm{t}}(\mathrm{t}$-table) or $5.409 \geq 1.691$. it meant that, the result of $\mathrm{t}$-test was higher than the value of table. The result of this analysis showed that the result t-test here was significantly effect of using Student Team Learning in reading comprehension at second grade students of MA Nurul Muhsinin JomangBatu Jai Lombok Tengah.

Based on the definition reading is active process that requires a great deal of practice 
and skill. It can be concluded that reading is an active process of guessing, and a complex interaction between the text and the reader, which was shaped by the reader's prior knowledge, experience, and attitude and language community.

Brown (2004: 189) stated that reading comprehension is a process of negotiating meaning; the reader brings to the text a set of schemata for understanding it, and intake is the product of that interaction. From the definition of reading the researcher found out many problems, such as the students were difficult to understand the reading text, second was the students' lack of vocabulary mastery, and the third students were find it difficult to find main ideas of reading texts. Therefore, the researcher applied Student Team Work Learning (STWL) strategy. In addition, Slavin (1977:3) argued that STWL strategy is when people working for a cooperative goal come to encourage one another to do their best, to help each other to do well, and to like and respect one another. Hence the students are presented with the work on assignments given by the teacher together.

There was only one statement of the problem proposed as follows: "Is there any significant effect of Student Team Work Learning (STWL) strategy towards students' reading comprehension at second grade students of MA Nurul Muhsinin Jomang Batu Jai Lombok Tengah?" this is statement of the problems had been answered based on the research result above.

Based on previous chapter, there were explained about the inferential analysis of comparison between t-test and t-table, where if t-test is higher than t-table, therefore Ha was accepted and Ho was rejected. Based on result above t- test was 5.411 higher than t-table was 1.692.

From the discussion, the researcher may draw conclusion that the use of Student Team Work Learning (STWL) strategy has significant effect towards students' reading comprehension. It means that $\mathrm{Ho}$ is rejected and $\mathrm{Ha}$ is accepted. Alternatively there was a significant effect of Student Team Work Learning (STWL) strategy toward second grade students reading comprehension of MA Nurul Muhsinin Jomang Batu Jai Lombok Tengah.

\section{CONCLUSION}

Based on this chapter, the researcher would like to propose to use Student Team Learning, which was proved from the result of experimental group's pre-test score was higher than control group. The researcher concludes that by using Student Team Learning the students' improved their reading in teaching learning process. Based on the statical analysis, the value of 
t-table was 1692 from (df) (35-1=34), it hypothesis was accepted. Meaning that, Student Team Learning strategy has many priorities effect second grade students reading comprehension of MA Nurul Muhsinin Jomang Batu Jai Lombok Tengah.

\section{REFERENCES}

Arikunto, Suharsimi. 2006. ProsedurPenelitianSuatuPendekatanPraktek, EdisiRevisi 2010.Jakarta: PT RinekaCipta.

Brown. 2004. Language Assessment Principles and Classroom Practices: Person education.

Chesla, Elizabeth. 2002. Exam Success in Only 6 Steps. Learning Express, LLC, New York.

Grellet, F. (1999).Developing Reading Skills.New York.Cambridge University Press.

Hennings, G.1986. Reading Comprehension for Special Needed Students. Boston: McGraw-Hill comp. inc.

Jeremy Harmer. 2007. How to Teach English. England: Person Longman.

Kothari, C.R.2004. Research Methodology Methods and Techniques.New Delhi: New age International (P) Ltd.

Miller, S. 2005. New Essential Physiology Experimental Design and Statistic Second Edition. London and New York :Routledge.

Sara S. Shapiro \& Ruth Ravid. (1989) Student TeamLearning in Jewish Schools, Journal of Jewish Education.

Slavin. 1977, Definition of Student Team Learning.

SitiFachraini. 2017. An Analysis of Students' Motivation In Studying English. (A Survey Study At Uin Ar-Raniry Banda Aceh). Getsempena English Education Journal

Syamsurrijal, S. (2020). Designing Life Skill-Based English Reading Materials for Second Grade Students Of Sma Negeri 1 Pringgasela. Humanitatis: Journal of Language and Literature, 6(2), 297-322.

Sugiono. 2016. MetodePenelitianPendidikanPendekatanKuantitative, Kualitative, dan $R \& B$. Bandung. Alfabeta.

Sugiono. 2017. StatistikauntukPenelitian. Bandung: ALFABETA 
